\title{
THE EFFECT OF DIET HABITS, PACKING, AND PRICE BARRIER ARE IMPACT ON ORGANIC FOOD PURCHASE BEHAVIOR
}

\author{
Sajid Hussain \\ Bahauddin Zakariya University Multan, Pakistan \\ E-mail: sajid.hussain6441@gmail.com \\ Sohaib Zafar \\ University of Education Lahore, Pakistan \\ E-mail: ik81638@gmail.com \\ Muhammad Baqir \\ University of Education Lahore, Multan campus, Pakistan \\ E-mail: baqiralisiddique@gmail.com
}

\begin{abstract}
Consumers purchase environmentally friendly products 'Organic food'. This study is applied in Pakistan a country in which there is concern about safety and quality. The "SEM' model is used to support our study. Three independent variables while one dependent variable is taken in that scenario. Data were obtained from 300 respondents, 278 backed us their response. We conclude from the above-mentioned model that the packing factor has much important than that of other variables. This sort of research can conduct in developed countries such as the US, CHINA, CANADA and other geographic areas. Also, green marketing factors can be replaced for future studies. Different independent variables contribute to future research like organic food labeling, lack of knowledge, and availability. We can also use different aspects such as environmental concern, health concern, and food safety concern using them as independent variables we can further use them in new research as a research gap. this research can also be done as longitudinal research.
\end{abstract}

Keywords: Diet Habits, Packing, Price Barrier, Organic Food.

\section{INTRODUCTION}

Over review of the statically figures across the globe elaborates amazing facts that a diet habit or diet consciousness has severed impact on the over windows of a region population (Dube \& labban, 2014). E. g if we look at the figure average life span of Norway and Japan .we have figure of 85.5 years and 83.98 years which are quit higher than the average global life span of 71 years. The reasons can be served but a clamp-sum can be summed up that the health values and stance on the diet consumption if we look at the diet consumption of Japan African countries 
.we can assume that there is no concept of diet consciousness in an Africa country due to lack of resources but also lack of proper channelization of awareness and importance .

Similarly, the use of an organic food or dietary fiber are important for health (smith \& paladinoa, 2010, 18) and (tanner, 2003) because also maintain a better hormonal and molecular level, but if we look at the consumption level of diet (Tent, food control 1999 , 10) and (wang, Shen, \& Goa, public Health 2018 , 15). A shocking revelation is found that there are severed factors which hinders the consumption level of organic items (Grunert \& Juhl, 1995, 16 ; Rana \& Paul, 2017 ) Awareness , Health consciousness , Lack of proper channelization , Quality standards , Packaging qualities, Pricing issues , Biotechnological lacking .

But we have to focused on only three of the factors which are Diet habits, packaging and pricing. lack of proper awareness to the public about the importance of the organic food in a daily routine, which is the responsibility of the health department and public health firms and also of the producing companies to aware the food (Hughner \& McDonagh, Behav. 2007 , 6 ; Magnusson \& Arvola, Br . Food J . 2009).

Similarly, the packaging and standard issues dramatically signifies its usage. India has played a very vital role in not only maintaining the quality but also increasing eye catching packing of all its products for local usage or export qualities (casieller \& Alvarez, 2005). While in case of organic products there are not taken such efficient steps that are helpful to organic products across the globe, consumer purchase the product by impressing packing services (Aaker, 2010). Information reaction are like packing, shapes, colors, and label are effect consumer respond positively.

The third vital factors of hindrance are the pricing of these products (Islam, 2016; Bryla, 2016 ; Verhoef, 2005 ; Mesias \& Gaspar Garcia, Br. Food j . 2012, 114) and it can be elaborated best by the example of china. Where nurseries have been made across the whole region with modern technologies to take tackle the seasoning issues of prices and quality organic products can be made available for the consumers across the year (Tanner, 2003) but such steps have only been taken by only few countries not by all.

\section{Significance}

This study assesses to price is device which is used to check consumer behavior and relation towards organic food. Some consumer purchase product by seeing packing of organic food.

\section{Research problem}

In it we try to check that to diet habits effect on organic food purchase behavior and to packing effect on consumer purchase behavior. We also check that to price barrier effect on consumer behavior products.

\section{Research question}

In it we try to check that How diet habits effect on organic food purchase behavior and How packing effect on consumer purchase behavior. We also check that How price barrier effect on consumer behavior products

\section{Diet Habits}

\section{LITERATURE REVIEWS}

For environmentally conscious customer organic product is matter of lifestyle choice (Sriram, 1993) . According to observation of (Davis, Titterington, \& cochrane, 1995) only 65\% of 
consumer go to buy organic products. (Hartman, 1998) research suggests that $48 \%$ of public want to purchase healthy and environment friendly products, consumer interest in health care through proper nitration is key factors that can influence consumption choice.

\section{Packing}

The buying behavior of consumer can be influenced by various packing factors which covers different areas as we mentioned above make unique organic diet from the other. In which package is substantial part. So, there is potential role of package color is influencing customer decision making process. Different mood is associated with different colors. More ever different colors have different meanings for customer. According to Singh (2006) Perception of color change across the culture. According to (charles \& Joe, 2011) product packing has four distinct function. It protects the product package color promotes the product. Finally, good product packing can protect the environment from damage. So, product packaging provides something extra them. Just protecting be product of company. Packing is the first thing that consumer see, So, it makes brand image in the mind of customer.

Labeling provide information about the product its category, ingredient's, and instruction regarding usage of products. According to Morris, J (1997) labeling helps to differentiate product more easily. Material of product packing help in protecting product from damage so high-quality material is likely to attract the customer so packing material also influencing buying behavior. (Hollywood, Wells, \& Farley, 2013) studied packing of milk. When customer buy a product first thing, he sees is product packing which plays important role to attract customers as well as children

\section{Price barrier}

Price is critical hurdle that present customer to buy organic food (Bryla, 2016 \& Verhoef, 2005). Consumer want to pay only for those products that has medium price. (Xie, Wnag, \& Zhang, 2015) conduct that $82 \%$ 0f respondents did not buying organic product due to high price. (Van , 2015) suggested that high prices of organic foods have negative impact on consumer perceived values.

A customer enters a shopping mall or a grocery store to buy his needs or necessity of daily life products but in the departure he has been impelled to buy several other products which were not on his priority list but still her had to buy (Von, Olea-jaik, \& padilla-Bravo, 2015). Now there are several reasons behind this interaction which are played by the stores or companies (Rana \& Paul, 2017 \& (Michaelidou \& Hassan , 2008). First of the all awareness or advertising and diet habits are viewed to make the customer know the importance the product (Rana, J.; Paul, J). Secondly, the packaging is made so amazing that it attracts the customer to gaze or review it (Keller, 2009) and thirdly, to impel the customer to make this item on his buying list. The price is made very affordable, to make him satisfactory to buy the product (Tanner, C.; Kast, S.W).

This article basically review about the lack of consumption of organic ingredients and product which play a very vital role in our life not only in health but also in physique but statically shows that across each continent the consumption level of such an important influencing product is used in a very minor quantity as compare to other commodities and luxuries. For example, if we compare the usage of soft drinks like cock and lemonades with the organic diet we can conclude that the beverages companies collects billions of dollars in revenue while keeping its disastrous side effect in view while products of organic supplementary are used 
or consumed in very small quantities in spite of its dietary and supplementary benefits. The main theme is the factors which are discussed in introduction Para play a significant role while consumption of these products.

Besides develop countries the inhabitance of other countries have a very low literacy about the health consciousness and awareness about the health issue while besides awareness the customer attraction is also one of the baggiest if the customer satisfaction and attraction is not met, the product or item cannot be sold out on that level which it should be.

\section{Research design}

\section{RESEARCH METHODOLOGY}

A search of knowledge is basically designed to conduct in different kind of people of Multan to purchase organic food were administered to collect data from people are impacting on organic food purchase behavior. Research design with minimal interference is conduct where survey method is used.

\section{Measure/instruments}

Questionnaire is basically a medium helping in investigation of collect data. The study instruments were divided into two section. First section is included demographic respondent. The research instruments consist of various questions related to the Diet habits, Packing, Price barrier and Organic food purchase behavior.

\section{Population and sampling}

The people in this study we Pakistani citizens aged from teenage-30 and from 30 to less than 40 years including the only people know which purchase organic food. From this study we will come to know about the knowledge to buy the organic food. The sources of data collection were paper based and online survey which are taken from different sources like from stores of the city Multan located in country Pakistan. In which 225 respondents respond on online survey and 53 respondents respond on paper-based survey and 22 respondents did not respond to the request.it took 3 weeks to collect the data. Total respondents were 278 from which we collect our data. The data collected from the respondent was not accurate some of the data was missing, out liar and normality of distribution. Sample size was 300 while only 278 people respond the survey. The male respondent was 180 which are $64 \%$ of our sample while the female were 97 which are $34.9 \%$ of our sample and one respondent did not give his or her biographic information. The ration of respondents (male and female) is 64:34.9. which is the part of our sample.

The respondents were divided into two categories based on age. First is from teenage to 30 and the other on is from 30 to less than 40. The frequency of the respondents aged from teenaged to thirty were 240 while the other one is from 37 lies in second category of age which is from 30 to less than 40 and missing system was the only one. The percentage of teenage to 30 is 86.3 percentage while the percentage from 30 to less than 40 is 13.3 percentage and the missing system contributed 0.4 percentage in the total sample.

The respondents were divided into three categories based on marital status. First one is single, second one is married while the third one is separated. Single responds were 200, married respondents were 70 while the separated were o7. And the missing value was the only one. The percentage of single respondents is 71.9 , percentage of married respondents is 25.2 while the percentage of separated respondents are 2.5 and the percentage of missing system is 0.4 . 
Respondents were divided in to three categories based on monthly income and pocket money. In first category their the respondents having the monthly income of less than $10 \mathrm{k}$. second category include the people having monthly income of $10 \mathrm{k}$ to $20 \mathrm{k}$ and in the third category the respondents having the monthly income of $21 \mathrm{k}$ and above. The respondents having monthly income of less than $10 \mathrm{k}$ were 178 which are 64 percentage of the sample, respondents having monthly income of $10 \mathrm{k}$ to $20 \mathrm{k}$ are 14 which are 5 percentage of the sample and the respondents having monthly income of $21 \mathrm{k}$ and above are 82 which are 29 percentage of the whole sample which the missing system are 3 which are 1.1 percentage of the sample . personal information of the respondents is shown in the table \# 1.

\section{Research model}

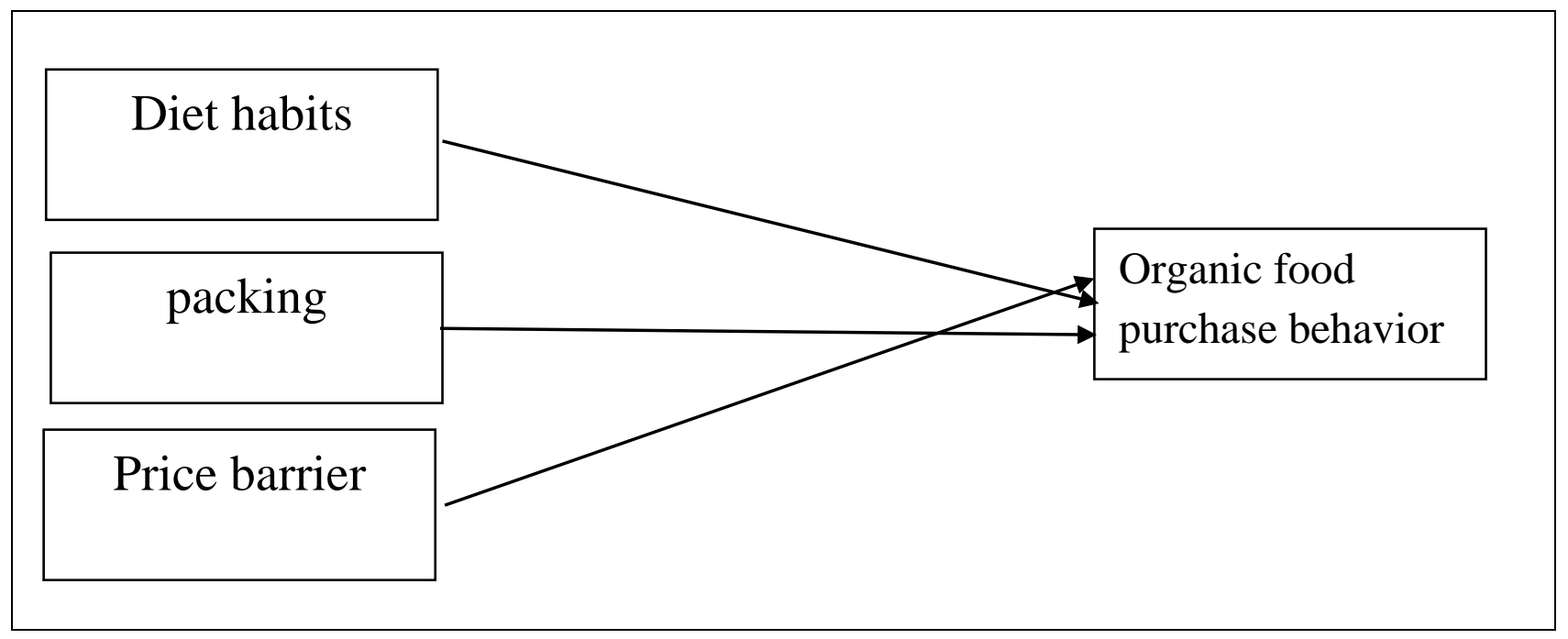

Figure 1: Research framework

\section{Hypothesis}

$\mathrm{H}_{1}$ : Diet habits has a positive effect on organic food purchase behavior.

$\mathrm{H}_{2}$ : Packing has a positive effect on organic food purchase behavior.

$\mathrm{H}_{3}$ : price barrier has a positive effect on organic food purchase behavior. 


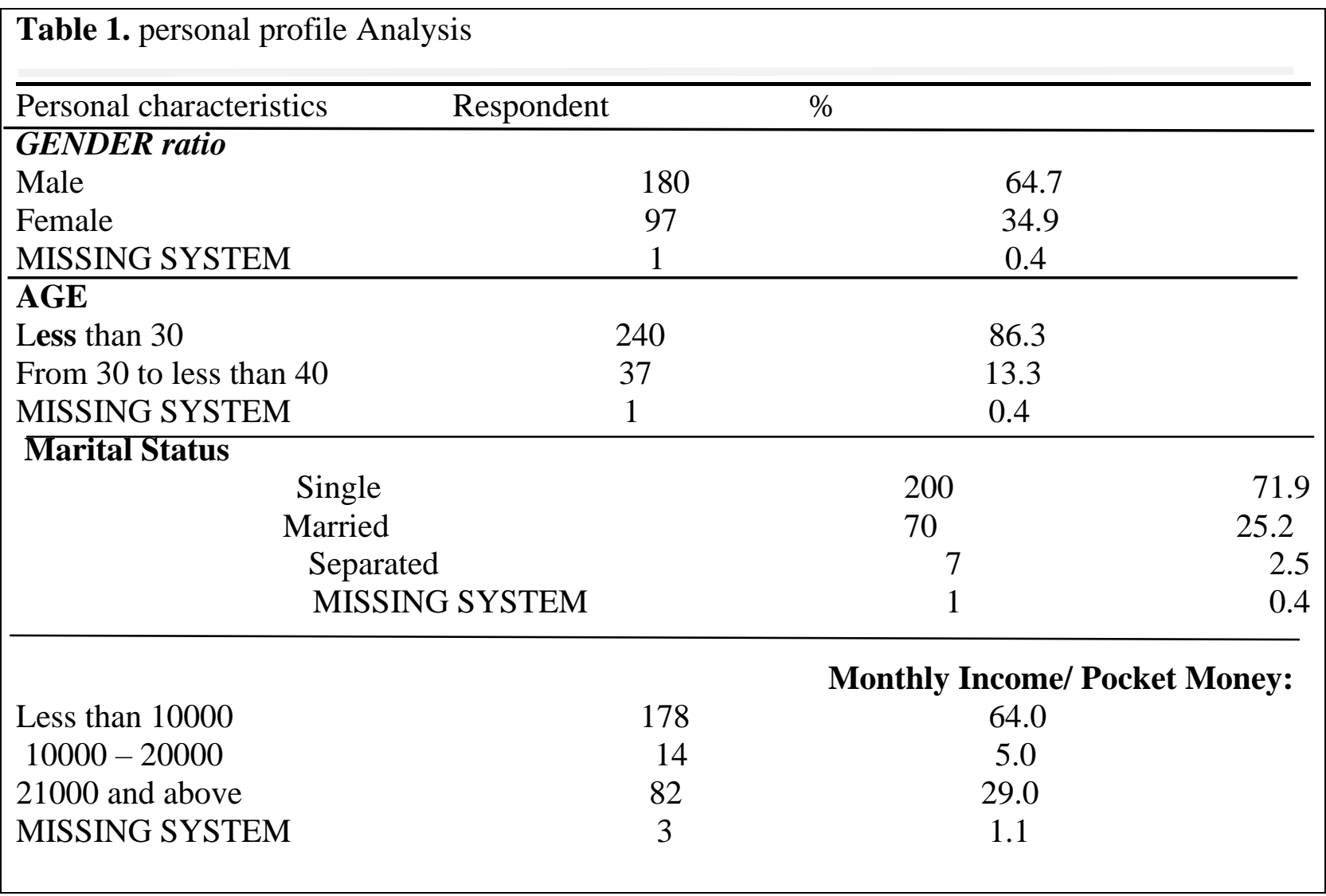

\section{DATA ANALYSIS}

Following the precautionary measure can confirmatory factors analysis (CFA) and reliability analysis and alpha $(\alpha)$ valued are measured were worked to asses construct validity and reliability. The confirmatory factors analysis is used to measure the validity of the construct and structure equation modeling (SEM) is tool to construct and measure hypothesis. Remember that organic food purchase behavior was measured by two items which are not acceptable in confirmatory factors analysis. In which SPSS version 21 is used for data analysis.

\section{Measurement model, construct reliability and validity}

To study the measurement model fit, all variables in the research model, except organic food purchase behavior were indicating toward confirmatory factors analysis utilizing maximum similarity estimations. The result of statistics is shown in table \# 2 .

\begin{tabular}{|l|l|l|l|l|l|}
\hline \multicolumn{6}{|c|}{ Table 2. Items, reliability and convergent validity } \\
\hline & Variables and items & fls & $\boldsymbol{\alpha}$ & CR & AVE \\
\hline & Diet habits & & 0.586 & 3.6927 & 0.461447 \\
\hline D1 & $\begin{array}{l}\text { I usually have the time to eat three } \\
\text { times/day }\end{array}$ & 0.802 & & & \\
\hline D2 & $\begin{array}{l}\text { I consume small quantities of food } \\
\text { frequently during the day }\end{array}$ & 0.664 & & & \\
\hline
\end{tabular}




\begin{tabular}{|c|c|c|c|c|c|}
\hline D3 & $\begin{array}{l}\text { I usually eat once during the day, } \\
\text { at home, due to my daily job }\end{array}$ & 0.669 & & & \\
\hline D4 & $\begin{array}{l}\text { I generally believe that I follow a } \\
\text { balance diet }\end{array}$ & 0.698 & & & \\
\hline \multirow[t]{2}{*}{ D5 } & $\begin{array}{l}\text { Fruits and vegetables are always } \\
\text { included in my daily diet. }\end{array}$ & 0.537 & & & \\
\hline & Packing & & 0.680 & 6.760834 & 0.359907 \\
\hline $\mathrm{P} 1$ & $\begin{array}{l}\text { The packaging color impacts } \\
\text { consumer behavior during buying } \\
\text { process }\end{array}$ & 0.654 & & & \\
\hline $\mathrm{P} 2$ & $\begin{array}{l}\text { The label of the package is } \\
\text { important in decision buying } \\
\text { process }\end{array}$ & 0.588 & & & \\
\hline P3 & $\begin{array}{l}\text { The quality of the packaging } \\
\text { material is important during } \\
\text { buying process }\end{array}$ & 0.661 & & & \\
\hline $\mathrm{P} 4$ & $\begin{array}{l}\text { The package design has an impact } \\
\text { on product selection during buying } \\
\text { process }\end{array}$ & 0.642 & & & \\
\hline P5 & $\begin{array}{l}\text { The printed information on the } \\
\text { package helps the process of } \\
\text { buying }\end{array}$ & 0.546 & & & \\
\hline P6 & $\begin{array}{l}\text { The language used on the package } \\
\text { influences consumer behavior } \\
\text { during the buying process }\end{array}$ & 0.547 & & & \\
\hline P7 & $\begin{array}{l}\text { The brand image on the package } \\
\text { has an impact on consumer } \\
\text { behavior on buying process }\end{array}$ & 0.640 & & & \\
\hline P8 & $\begin{array}{l}\text { Innovation and practicality is } \\
\text { important in consumer buying } \\
\text { process }\end{array}$ & 0.540 & & & \\
\hline \multirow[t]{2}{*}{ P9 } & $\begin{array}{l}\text { The quality of packaging is related } \\
\text { with the price of the product }\end{array}$ & 0.564 & & & \\
\hline & Price barrier & & 0.553 & 2.84953 & 0.38349 \\
\hline PB1 & Organic meat is still too expensive & 0.755 & & & \\
\hline PB2 & $\begin{array}{l}\text { The price of organic meat is a } \\
\text { barrier to purchase it }\end{array}$ & 0.554 & & & \\
\hline \multirow[t]{2}{*}{ PB3 } & $\begin{array}{l}\text { People should buy organic meat, } \\
\text { even though they are more } \\
\text { expensive than conventional meat }\end{array}$ & 0.523 & & & \\
\hline & Organic food purchase behavior & & 0.238 & 4.20621 & 0.54197 \\
\hline P.B1 & I usually purchase food & 0.830 & & & \\
\hline P.B2 & I usually spend for food weekly & 0.736 & & & \\
\hline
\end{tabular}




\begin{tabular}{|l|l|l|l|l|l|}
\hline P.B3 & I purchase at local store & 0.813 & & & \\
\hline P.B4 & I purchase at supermarket & 0.584 & & & \\
\hline P.B5 & I purchase at hypermarket & 0.562 & & & \\
\hline P.B6 & I purchase at specialty shops & 0.758 & & & \\
\hline P.B7 & I purchase at open market & 0.819 & & & \\
\hline
\end{tabular}

As suggested by construct validity was tested using convergent and discrimination validity. Convergent validity is based on three factors or conditions. The one conditions is standardized factors loading, second one is composite reliability (CR) and the third factor is Average variance extracted (AVE).

In diet habits there are five items which have the factors loading of $0.802,0.664,0.669$, 0.69 and 0.537 respectively. The factors loading is between $0.537-0.802$. The composite reliability value of diet habits is 3.6927 and average variance extracted value is 0.461447 . In packing there are nine items which have the factors loading of $0.654,0.588,0.661,0.642,0.546$, $0.547,0.640,0.540$ and 0.564 . The factors loading lies in $0.540-0.661$. The composite reliability value of 6.760834 and average variance extracted value is 0.359907 . In price barrier there are three items which have the factors loading of $0.755,0.554$, and 0.523 respectively. The factors loading is between $0.523-0.755$. The composite reliability value of price barrier is 2.84953 and average variance extracted value is 0.38349 . In organic food purchase behavior, there are seven items which have the factors loading of $0.830,0.736,0.813,0.584,0.562,0.758$, and 0.819 respectively. The factors loading is between $0.562-0.830$. The composite reliability value of organic food purchase behavior is 4.20621 and average variance extracted value is 0.54197 . The average variance extracted value of all four variable lies between $0.359907-6.760834$ and composite reliability value is lies between $2.84953-6.760834$. The alpha value lies between $0.238-0.680$. discrimination validity of correlation is heterotrait - monotrait (HTMT) are also shown in table \# 3.

Table 3. Descriptive statistics and discriminant validity.

\begin{tabular}{|lccccccc|}
\hline Construct & \multicolumn{1}{c}{ MeanSD } & diet habits & packing & price barrier & organic \\
\hline Diet habits & 3.6754 & 0.64889 & 1 & & & & \\
Packing & 3.9714 & 0.49349 & 0.475 & 1 & & \\
Price barrier & 3.8430 & 0.70690 & 0.447 & 0.506 & 1 & \\
Organic food & 1.9953 & 0.36886 & -0.86 & -0.119 & -0.74 & 1 \\
\hline
\end{tabular}

\section{Hypothesis testing}

The structure equation modeling was applied on three hypotheses. The result of the hypothesis is shown in table \# 4. we examine the effect of diet habits, packing and price barrier on organic food purchase behavior. from the hypothesis we conclude that $\mathrm{H} 1$ and $\mathrm{H} 3$ are rejected while $\mathrm{H} 2$ are accepted. $\mathrm{H} 1$ has the $\beta$ value is -0.05 and $\mathrm{p}$ value / significant value is 0.112 and standard error is 0.03 and $\mathrm{t}-$ value is -1.595 . $\mathrm{H} 2$ has the $\beta$ value is -0.098 and $\mathrm{p}$ value / significant value is 0.03 and standard error is 0.045 and $\mathrm{t}-$ value is -2.18 . $\mathrm{H} 3$ has the $\beta$ value is -0.036 and $\mathrm{p}$ value / significant value is 0.256 and standard error is 0.032 and $t-$ value is -1.137 . The value is shown in the table \# 4. 
Table 4. SEM (structural equation modelling) results and hypotheses testing.

Hypotheses

$\beta$ S.E. T-value p-value

finding

H1: Diet habits $\longrightarrow$ purchase behavior $-0.05 \quad 0.034 \quad-1.595 \quad 0.112$ Not accepted

H2: packing $\longrightarrow$ purchase behavior $\quad-0.098 \quad 0.045 \quad-2.18 \quad 0.03 \quad$ Accepted

H3: price barrier $\longrightarrow$ purchase behavior $-0.036 \quad 0.032 \quad-1.137 \quad 0.256$ Not accepted

DISCUSSION, IMPLICATION, AND LIMITATION

This study gains through experience and declared a model gathering important key elements or components of different or varies theories to gather organic food purchase. From structure equation modeling it is clear that packing is key tool used to attract customer in Multan. The research gap for future study is the study in different countries on organic food purchase. The study can be extended in both the developed and underdeveloped countries such as Pakistan, India, Indonesia, USA, China and etc. findings statistic there is reverse relation between price and customer for organic food. Another variable is also added in future studies which is green marketing which directly influence on purchase frequency on organic food. Different markets also influence on organic food purchasing

The limitation of the study is divided into four major categories. First, the sample size of the research is not so long we can conclude the urban areas of Pakistan as well in our studies. that might affect the purchase frequency of organic food. second, interpretation between the variable may be also exits in the future studies like diet habits, packing and price barrier. Third, hurdle to buy organic food were represented only by price barrier, Low income people cannot buy the organic food due to the high prices. Fourth, this study includes the data collected in the same time period. This may be happening that the income; purchase frequency of the people can be changed due to time.

\section{CONCLUSION AND FUTURE RESEARCH}

This study emphasizes on the variable of diet habits, packing and price barrier on organic food purchase behavior. The finding highlights of our research are diet habits, packing and price barrier which are the gap of our research and the data is collected in the market of Multan. The gap described the negative impact of organic food purchase behavior while the diet habits and price barrier have a negative impact in our hypothesis and packing has a significant impact in our hypothesis. personal factors include diet habits and packing, and environmental factors is price barrier which describe or explain the impacts on purchasing of organic food.

Our framework can also use in merging market economics. Furthermore, the information gathered from the respondents can also be collected from different cities of Pakistan like Islamabad, Lahore, Karachi and etc. Data can be collected from urban areas and rulers' areas respectively. The income of ruler areas having low while the income of urban areas are high due 
to the change in their life pattern and the purchase frequency of urban areas are high as compare to ruler areas.

Different independent variables contribute in future research like organic food labeling, lack of knowledge and availability. we can also use different aspects such as environmental concern, health concern and food safety concern using them as independent variables we can further use them in new research as a research gap, this research can also be done as longitudinal research.

\section{REFERENCES}

Aaker. (2010). organic food purchase behavior in the market. 205-207.

Bryla, P. (2016). Organic food consumption in poland: Motives and barriers. Appetite, 105 , 737 746.

Casieller, \& Alvarez. (2005). organic food. 189-875.

Charles, W., \& Joe, F. (2011). Essential of marketing: A marketing strategy planning approach. cengage Learning.

Davis, A., Titterington, A., \& cochrane, C. (1995). Who buys organic food? A profile of the purchaser of organic food in N.ireland. British Food Journal, Vol. 97 No. 10, pp. 17-23.

Dube, L., \& labban, A. (2014, 1331). A nutrition/health mindset on commercial big data and drivers of food demand in modern and traditional systems. Ann. N. Y. Acad. sci, 278-295.

Grunert, S. C., \& Juhl, H. J. (1995, 16). Values, environmental attitudes, and buying of organic foods. J . Econ . psychol, 39-62.

Hartman, H. (1998). Consumer and retailer interest in eco labeling, eco labeling for california winegraps: . working conference proceeding, pp. 11-14, 4 February, Sacramento, available at www.sarep.ucdavis.edu.

Hollywood, L., Wells, L., \& Farley, H. (2013). Thinking ourside the carton: attitude towareds milk packing. British Food Journal, 115(6), pp. 889-912.

Hughner, R. S., \& McDonagh, P. (Behav. 2007 , 6). Who are organic food consumers? A compilation and review of why people purchase organic food. J . consum , $94-110$.

Islam, K. M. A. (2016). Factors Influencing Consumers Purchase Decision: A Case Study of Pantene Shampoo. Indian Journal of Science, 23(88),910-923.Retrieved from https://discoveryjournals.org/science/current_issue/2016/A74.pdf

Magnusson, M., \& Arvola, A. (Br . Food J . 2009). Attitudes towards organic foods among swedish consumers. A review, 1140-1167.

Mesias, D., \& Gaspar Garcia, P. (Br. Food j . 2012, 114). consumer knowledge, consumption, and willingness to pay for organic tomatoes. 318-334.

Michaelidou, N., \& Hassan, L. (2008). The role of health consciouness, food safety concern and ethical indentiy on attitudes an dintention towards organic food. 163-170.

Rana, J., \& Paul, J. (2017 ). Consumer behavior and purchase intention for organic food: A review and research agenda. $j$.Reatail . consum, 157-165.

Reisch, L., Eberle, U., \& Lorek, S. (policy 2013). Sustainable food consumption: An overview of contemporary issues and policies. sustani. sci. pract, 9, 7-25.

Smith, s., \& paladinoa. $(2010,18)$. Eating clean and green? Investigating consumer motivations towards the purchase of organic food. Australas. Mark.J, 93-104.

Sriram, V. a. (1993). The relative importance of product environmental attributes: a crossculture comparison . international marketing review, Vol. 10 No 3, pp.51-70. 
Tanner. (2003). determination of green purchase products. 20.

Tanner, C. (2003). green purchase product of determine. 20.

Tent, H. (food control 1999,10 ). Research on food safety in the 21 st century. 239-241.

Van , D. J. (2015). Drivers of and barriers to organic purchase behavior. J. Retail. 436-450.

Verhoef, p. (2005). Explaining purchases of organic meat by dutch consumers. Eur . Rev . Agric. Econ, 32 , 245-267.

Von, M.-H. M., Olea-jaik, E., \& padilla-Bravo, C. (2015). Mature and emerging organic markets: Modelling consumer attitude and behaviour with partial least square approach. 626-653.

Wang, j., Shen, M., \& Goa, Z. (public Health 2018 , 15). Research on the irrational behavior of consumers' safe consumption and its influencing factors. int. $j$. Envirom . Res, 2764.

Xie, B., Wnag, L., \& Zhang, M. (2015). consumer perceptions and attitudes of organic food products in eastern china. Br. Food J . 1105-1121.

\section{APPENDICES}

\section{Appendix-A: Questionnaire}

Dear respondent; I am the student of Bahauddin Zakariya university Multan, working topic "The effect of Diet habits, packing, and price barrier are impact on organic food purchase behavior. This questionnaire is designed to get your response about this research, and I hope so you will fill this questionnaire with full attention and devotion. Thank you.

\section{PERSONAL DETAILS:}

- Gender: Male ( ) Female ( )

- AGE: Less than 30 ( ) From 30 to less than 40 ( )

- Marital Status: Single( ) Married ( ) Separated ( )

- Monthly Income/ Pocket Money: Less than 10000 ( ) 10000 - 20000( )

21000 and above ( )

- Occupation: Self-employed/ Business( ) Professional/ Job Holder( )

\begin{tabular}{|l|l|l|l|l|l|l|}
\hline Sr. & Questions & $\begin{array}{l}\text { Strongly } \\
\text { disagree=1 }\end{array}$ & Disagree=2 & Neutral=3 & Agree=4 & $\begin{array}{l}\text { Strongly } \\
\text { agree=5 }\end{array}$ \\
\hline & Diet habits & & & & \\
\cline { 2 - 5 } & $\begin{array}{l}\text { https:/www.emerald.com/insight/co } \\
\text { ntent/doi/10.1108/000707002104431 } \\
10 / \text { full/html }\end{array}$ & & & & & \\
\hline D1 & $\begin{array}{l}\text { I usually have the time to eat } \\
\text { three times/day }\end{array}$ & & & & & \\
\hline
\end{tabular}




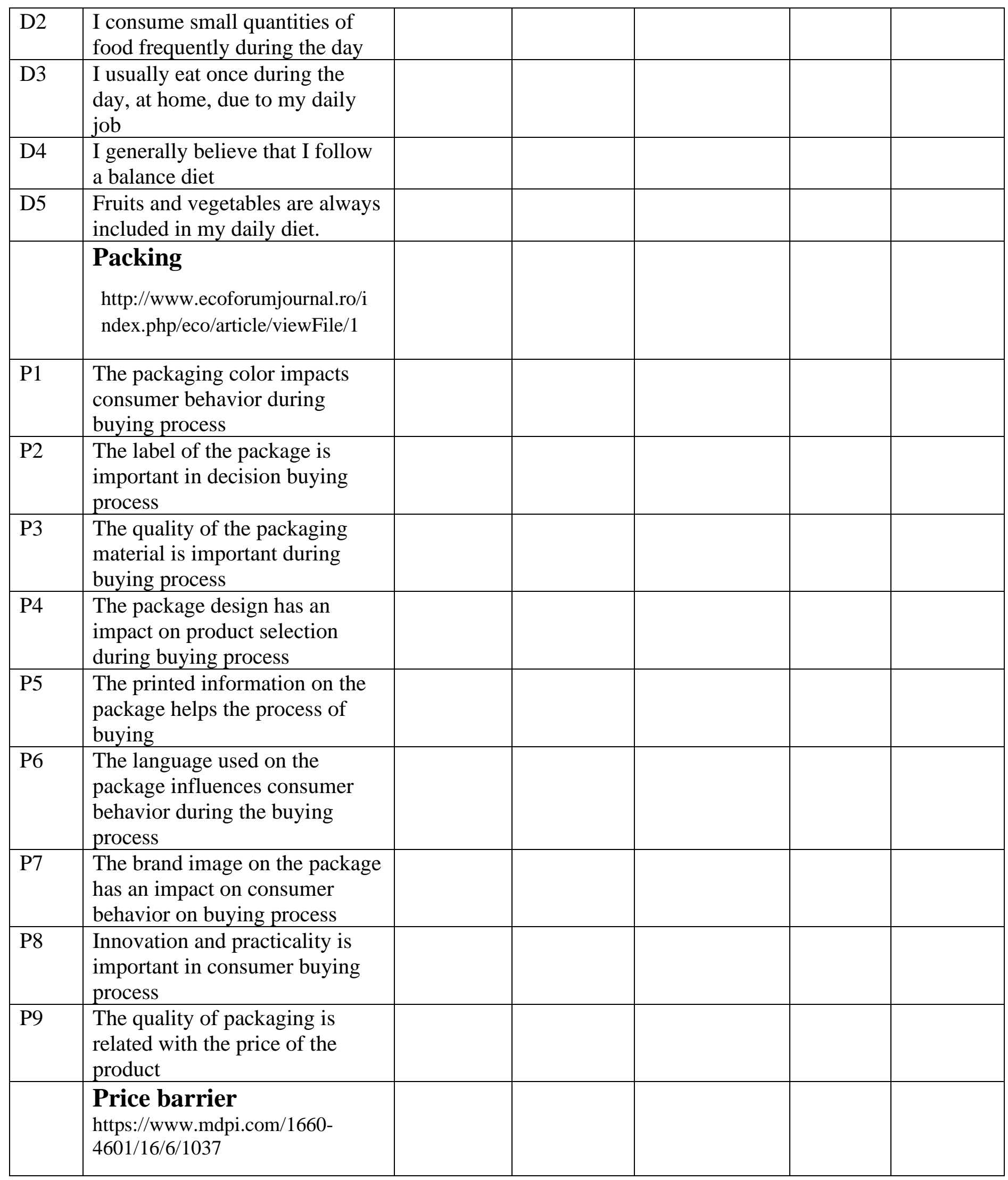




\begin{tabular}{|l|l|l|l|l|l|}
\hline PB1 & $\begin{array}{l}\text { Organic meat is still too } \\
\text { expensive }\end{array}$ & & & & \\
\hline PB2 & $\begin{array}{l}\text { The price of organic meat is a } \\
\text { barrier to purchase it }\end{array}$ & & & & \\
\hline PB3 & $\begin{array}{l}\text { People should buy organic meat, } \\
\text { even though they are more } \\
\text { expeat }\end{array}$ & & & & \\
\hline
\end{tabular}

\begin{tabular}{|l|l|l|l|l|l|}
\hline & \multicolumn{2}{|l|}{$\begin{array}{l}\text { Purchase behavior } \\
\text { https://www.emerald.com/insig } \\
0210443110 / \text { /full/html }\end{array}$} & & & \\
\hline P.B1 & I usually purchase food & Once/week ( ) & More than once( ) & Less than once ( ) & \\
\hline P.B2 & $\begin{array}{l}\text { I usually spend for food } \\
\text { weekly }\end{array}$ & <Rs100 ( ) & Rs 100-150 ( ) & >Rs 150 ( ) & \\
\hline P.B3 & I purchase at local store & frequently & Rarely & Never & No answer \\
\hline P.B4 & I purchase at super market & frequently & Rarely & Never & No answer \\
\hline P.B5 & I purchase at hypermarket & frequently & Rarely & Never & No answer \\
\hline P.B6 & I purchase at specialty shops & frequently & Rarely & Never & No answer \\
\hline P.B7 & I purchase at open market & frequently & Rarely & & \\
\hline
\end{tabular}

\section{Copyrights}

Copyright for this article is retained by the author(s), with first publication rights granted to the journal. This is an open-access article distributed under the terms and conditions of the Creative Commons Attribution license (http://creativecommons.org/licenses/by/4.0/) 